\title{
Grasping the Ungraspable in M. NourbeSe Philip's Poetry
}

\section{Myriam Moïse}

\section{(2) OpenEdition \\ 1 Journals}

Electronic version

URL: https://journals.openedition.org/ces/8292

DOI: $10.4000 /$ ces.8292

ISSN: 2534-6695

\section{Publisher}

SEPC (Société d'études des pays du Commonwealth)

\section{Printed version}

Date of publication: 1 September 2010

Number of pages: 23-33

ISSN: 2270-0633

\section{Electronic reference}

Myriam Moïse, "Grasping the Ungraspable in M. NourbeSe Philip's Poetry", Commonwealth Essays and Studies [Online], 33.1 | 2010, Online since 11 December 2021, connection on 20 January 2022. URL: http://journals.openedition.org/ces/8292 ; DOI: https://doi.org/10.4000/ces.8292

\section{(c) (1)}

Commonwealth Essays and Studies is licensed under a Licence Creative Commons Attribution - Pas d'Utilisation Commerciale - Pas de Modification 4.0 International. 


\section{Grasping the Ungraspable in M. NourbeSe Philip's Poetry}

This article investigates M. NourbeSe Philip's recent collection of poetry, Zong! (2008) in which the poetess attempts to reconstruct history and extend the limits of memory. The book recounts the 1781 story of the slave ship Zong, whose captain threw 132 African slaves overboard for the insurance money. The traumatic story is told through fragments of voices and memories through which Philip unsettles the forms of canonical English poetry and exploits the limits of the page. Her writing encourages the reader to share her African spiritual quest and her triangular journey from the Caribbean to Canada and back to West Africa. Philip's poetry demonstrates how boundless diasporic spaces can be, as the Diaspora displaces home and away, here and elsewhere, thus constantly redefining the limits of its own horizon.

The sea is slavery... Sea receives a body as if that body has come to rest on a cushion, one that gives way to the body's weight and folds round it like an envelope. Over three days 131 such bodies, no, 132, are flung at this sea. Each lands with a sound that the sea absorbs and silences... Those bodies have their lives written on salt water. The sea current turns pages of memory. One hundred and thirty one souls roam the Atlantic with countless others. When the wind is heard, it is their breath, their speech. The sea is therefore home. (D'Aguiar 1997, 1)

o begins Guyanese writer Fred D'Aguiar's Feeding the Ghosts, a novel which recounts the 1781 massacre of one hundred and thirty-two African slaves. It all started when the Zong captain Luke Collingwood became aware that his inexperience had led his ship off course, that his water and food supplies had run out and that his "cargo" would perish before reaching his final destination. He then decided that the only way to collect the insurance money, and to guarantee his own profit and that of the Liverpool vessel's owners' was to have the sickly slaves drowned. D'Aguiar's neo-slave narrative forces us to reconsider

[...] the question of value as a problem of naming and seeing: of knowing how to name what we see and how to value what we name when we view this event from a distance of two hundred years, or indeed from whatever distance separates the viewing of such an atrocity from this atrocious scene. (Baucom 61)

In her latest poetry collection Zong!, ${ }^{1}$ Caribbean Canadian poet M. NourbeSe Philip raises the question of point of view, and challenges the reader to reconsider the established order, to see beyond imposed limits, as she deliberately seeks to reconstruct history, to voice the unspeakable and to extend the limits of memory.

1 I am grateful to Marlene NourbeSe Philip for kindly giving me permission to quote extensively from this work. 
Philip's own version of the Zong massacre is told through fragments of voices, memories, and silences. The poetess tells a story that cannot be told but must still be told by not telling. Her attempt to make silence speak and to express the inexpressible seems to answer diasporic Jamaican poet Lorna Goodison's lyrical appeal in "Mother, the Great Stones Got to Move." Goodison addresses the untold history of slavery in Jamaica and the necessity for Caribbean peoples to fill the gaps of their own history:

Mother, one stone is wedged across the hole in our history

And sealed with blood wax. [...]

It is the half that has never been told, some of us

Must tell it. (Goodison 4)

In order to voice "the half that has never been told" and to give her side of the story, NourbeSe Philip exploits the silent archival material. As she states in $A$ Genealogy of Resistance, her aim is to make the black hole (w)hole (Philip 1997, 101). Unsettling the forms and testing the limits of the page, she forces her readers to experience her African spiritual quest. To some extent, the poet re-engages her readers, inciting them to re-build their history and to re-connect their past with their present. She author(ize)s her story to cross the frontiers of the "unspeakable" and of the unspoken to reach the status of the "unspeakable things spoken at last" (Morrison 214). This article will observe how the diasporic Caribbean writer transcends her traumatic past and overcomes silence to (re)map new horizons.

In a recent interview about her work, NourbeSe Philip interrogates meaning and value and defines her Zong! poetry collection as an attempt to come to terms with meaninglessness:

We discern flashes of meaning, or we construct meaning from the apparent meaninglessness of the page. How do you/we make meaning of the apparently meaningless? How do you make meaning of the deliberate massacre of 150 people to collect insurance monies? How do we make meaning of 400 years of peoples being uprooted, kidnapped and taken half way around the world? To what end? I think we are hardwired as humans to try to make meaning. Zong! is an attempt to write, to come to terms with the meaninglessness of so much that passes for life. (Philip 2010)

Making sense out of the meaningless, grasping the ungraspable, and voicing the unspeakable: from her earliest writings, Philip has been expressing the complexities of working against silence and fragmentation. In the original letter covering the manuscript of She Tries her Tongue, she underlines the difficulties to write poetry when faced with the dual realities of her race and gender:

How does one write poetry

How does one -

Poetry from the twin realities

Black and female

One doesn't. The realities aren't twin. Or even same. 
Admitting the complex realities of her black female identity, the author further emphasises her anxiety about using the English language, a medium fraught with ambiguity, as it was once complicit with slavery and subjugation:

How does one write poetry

from the perspective of "mastery" of a mother

tongue __a foreign language

an anguish

One doesn't. One fashions a tongue

Split two times two times two

into

poly\&

multi\&

semi vocalities. (Philip 1997, 120-121)

The multiplicity of languages, identities and voices, the same twin realities, both Caribbean and Canadian, the impossibility to grasp the ungraspable and to work against fragmentation... all these issues are magnified throughout her formal experiments in Zong! The book engages with a poetry of rupture whose nature and meaning Philip exploits to reach an eventual wholeness. Its very structure embodies both fragmentation and wholeness. It consists of six different sections which, at times, are divided into a series of numbered poems in a variety of lengths, shapes and rhythms, and, at other times, are left as a whole. Zong! was born out of fragmentation, since the poet actually makes use of the fragments of the archival legal material from the Zong trial to reconstruct a different text in which the previously ignored African voices are imaginatively acknowledged. The last poem in the first section entitled "Os" illustrates the poet's reflections on how such a tragedy could have possibly occurred:

was the cause was the remedy was the record was the argument was the delay was the evidence was overboard was the not was the cause was the was the need was the case was the perils was the want was the particular circumstance was the seas was the costs was the could was the would was the policy was the loss was the vessel was the rains was the order was the that was the this was the necessity was the mistake was the captain was the crew was the result was justified was the voyage (45)

Beginning and ending with "was the cause," this poem concludes the first section of the book. It conveys a feeling of suffocation and confusion while focussing on what could have accounted for the event. In Zong!, words such as "justify," "authorize," "cause" and "could" are used extensively, relaying the author's physical initiatory quest for explanation and evidence. The arrangement of the words on the page also demonstrates Philip's wish to intertwine the voice of the master and the voices of the slaves. Words such as "captain," "maps" and "declaration" belong to the vocabulary of authority and command. As such, they can be associated with the master, whereas other words - for instance "water," "winds," "weeks," 
"rains," "destroyed," "uncommon" and "apprehension" - evoke the plight of the slaves. The presence of the slave is given prominence through the poetic voice, and it is certainly an authorial strategy to focus on the slave personae, since the original legal text did not consider the Zong episode as a human tragedy. Other words such as "remedy" retain some ambiguity, as it could both refer to the remedy that would allow the African slaves to survive (water and food), and to the drowning the captain eventually opted for to ensure his financial survival. Water and drowning are in fact omnipresent in this excerpt and in the whole poem through the use of recurrent alliterations in $[\mathrm{w}]$ as well as through the suffocation suggested by the visual compactness and semantic opacity of the poem.

The opening poem, however, is less opaque and more airy, as its composition exploits the splitting of words to its fullest. The dominance of alliterations in $[\mathrm{w}]$ and [d] echoes the tragic descent into the water. The words "water," "awa" or "agua" recur insistently in reference to the powerful sea water which swallowed the African bodies. The names of slaves listed at the very bottom of the page magnify their descent into the water, and the footnote line may symbolize the ungraspable horizon, the unreachable surface of the water. Their names also epitomize their spiritual survival despite their physical murder, reminding us of the importance of ancestry in African culture. Fred d'Aguiar and Derek Walcott both agree when they respectively write "The Sea is Slavery" (D'Aguiar 1997, 1) and "The Sea is History" (Walcott 30-32). NourbeSe Philip concurs with them in the afterword to Zong!:

Our entrance to the past is through memory - either oral or written. And water. In this case, salt water. Sea water. And, as the ocean appears to be the same yet is constantly in motion, affected by tidal movements, so too this memory appears stationary yet is shifting always. Repetition drives the event and the memory simultaneously, becoming a haunting, becoming spectral in its nature. (201)

Memory is thus haunting and, in order to express the inexpressible story of the Zong, NourbeSe Philip names her African ancestors and deploys fragments of words from European and African languages to convey meaning. The names of African deities - for instance, Osun and Awa, both of whom are water goddesses (Murphy and Sanford 237) - recur as frequently in the poem as words such as "deo" and "deus" meaning "God" in Latin. In an interview, the writer insists on the fact that "the slave ship was a globalised world, a multilingual globalised prison on the sea that was a part of the first globalisation - the globalisation grounded on black skin and bills of exchange that fuelled and initiated speculative financing." She adds that "when Columbus set sail in 1492, the Spanish Crown began the thrust to reduce the many languages of Spain to one." (Philip 2010) The history of Spain is in fact linked with the Spanish Crown's imposition of the Castilian language and their consequent efforts to use linguistic domination to spread Castilian nationalist values across the peninsula. In her poetry, NourbeSe Philip challenges the Eurocentric movement from fragmentation to wholeness 
as she plays on the multiplicity of languages and voices. Thus acknowledging the African multi-vocal culture, NourbeSe Philip constructed Zong! as a lyrical mix of English, Spanish, French, Dutch, Patois, Latin and African languages, predominantly Yoruba and Shona. This innovative linguistic combination echoes Mexican poet Rosario Castellanos's vision of the necessity for Third World women writers to construct a new language of their own:

We have to create another language, we have to find another starting point, search for the pearl within each shell, the pit beneath the peel, because the shell holds still another treasure, the peel another substance. Word is the incarnation of the truth, because language has meaning. (Castellanos 76)

The poem allows the story to tell itself through a poetics of fragmentation and word splitting. The penultimate section entitled "Ferrum" is one of the most disjointed sections in the collection. It stands out as a single unit, a 46 page-long poem; its pages are often densely covered in print, which contrasts with the sparse lay-out of the opening section. "Ferrum" means "iron" in Latin. The sonorities of the word strongly echo Aimé Césaire's poetry collection Ferrements, a coinage which evokes the noun enfermement (i.e. "imprisonment") and puns on French words for iron, chains, and keys, all of which operate in the poem as synecdoches for the slave trade. Fragmentation could therefore be linked to the breaking of chains, and thus to freedom of movement. In "Ferrum," the repleteness of the page creates an impression of saturation, recalling the black bodies of the drowned slaves floating on the surface of the ocean. The circular arrangement of the words on certain pages may also serve to stress that Philip writes against linearity and hierarchy. As explained by the poet herself, her governing rule is that no word should come directly below another word. Words are to seek the space above within which to position themselves:

In "Ferrum," I felt that the fragmenting of the words - primarily English words but the fragmenting of language, allowed for another language to emerge. It felt, at times, as if I were writing a code and did feel I was having my revenge on the English language in a very deep sense - this foreign anguish that had choked and stifled us at the level of speech and thought - at last I could breathe; the fracturing allowed me to breathe. In English. For the first time. (Philip 2010)

Indeed, not only does NourbeSe Philip retrace the Atlantic journey onboard the Zong, but she also redefines the English language with regard to African culture. Put differently, she reconstructs it so that it may suit the demands of recounting such a tragedy. For instance, her extensive use of an animal lexical field serves to evoke the treatment of slaves as animals and also the Darwinian theory of the "Survival of the Fittest." In fact, the "seriation" (Dupriez 414) created by the juxtaposition of coordinated elements conveys an implicit message:

that rat it

ate the cat or is 
it the cat that

ate the rat halve

the ration of (127)

This excerpt emphasises the poet's obsession with quantity, as the tragedy of the Zong is about numbers - the number of slaves drowned because of money, and the number of clauses on the ship's insurance contract. The importance of quantity also lies in the rationing of water and food. The reversal between the cat and the rat in the survival game also denotes some ambiguity, perhaps a reflection on the initial role of African chiefs in the slave trade. This reversal may also echo the fate of the European sailor who eventually commits suicide, throwing himself overboard, linking his fate to that of the 132 slaves. In fact, as Philip explains in the afterword:

One of the strongest voices in the Zong! text is that of someone who appears to be white, male, and European. [...] we are at least one and the Other. And the Other. And the Other. That in this postmodern world we are, indeed, multiple and many-voiced. (204)

The Babelian chorus of voices thus comprises the voices of the captain, the European crew and the slaves. The introduction of words from other European and African languages allows a new tongue to be tried, new tunes to be heard, but it also serves to destabilize the reader's established construction of meaning: "what the multiplicity of idioms actually limits is not only a 'true' translation, a transparent and adequate inter-expression, it is also a structural order, a coherence of construct." (Derrida 218) In fact, Philip's play on words extends to different languages and further deconstructs meaning, as the recurrent use of "bones" or "os" conveys the poet's obsession with the only thing remaining after death.

In Zong!, the letters composing the French word "os" [bone(s)] are used to materialise the drowning on the page, as the poet recreates the slaves' S.O.S, ("Save Our Souls"), their distress call while trying to survive. The scattered letters are reminiscent of the bubbles produced by the last lungful of air, symbolizing distress and the descent into the deep. Numerous alliterations in [s] ("save," "salve" and "soul") create a dynamic pattern imposing the notion that besides the bones, the souls remain and are to be saved. The poet's insistence on bones also denotes the importance she places on identities, since the skeletal record is the only material evidence which endures after the slaves disappear from sight, after their individual identities have been fragmented and displaced through the continuum of the Middle Passage. Identity and being are two important concerns in Zong! In the section entitled "Os", and especially in poem \# 21, Philip plays on notions of being and not being, thereby questioning definitions of humanity, which leads to the implicit indictment of slavery as a crime against humanity. Absence of being is linked to the oppressive presence of the blank on the page, a visual effect which arguably represents the historical voicelessness of African Caribbean women. As a matter of fact, silence is fundamental for the diasporic 
woman writer, the Third World writer, the woman of colour and more generally the subaltern female subject who engages with silence in her creative work:

Sometimes our work is talking. Sometimes our work is simply being, experiencing feelings and thoughts we've put so far away we have no words for them. Then the silence and our breathing allow these feelings to find shapes and sounds of the words we need. (Ntozake Shange 179)

In the afterword to her first novel, The Bluest Eye, Toni Morrison also speaks of the way her story was, first and foremost, an effort to "shape a silence" while "breaking it" at the same time (Morrison 216). Likewise, silence is depicted as ambivalent by Japanese Canadian poet and activist Joy Kogawa, who distinguishes a silence that speaks from "a silence that cannot speak," "a silence that will not speak":

Beneath the grass of speaking dreams and beneath the dreams is a sensate sea.

The speech that frees comes from that amniotic deep.

To attend its voice, I can hear it say, is to embrace its absence.

But I fail the task. The word is stone. (Kogawa 1)

For these women writers, silence is first an obstacle to overcome as they aspire to speak against it through their testimonies and their own interpretation of history, justice and society. Yet, while Kogawa expresses her failure to embrace silence on the page, one may wonder whether NourbeSe Philip manages to voice silence and to allow her trans-cultural speech to emerge. From her earliest work onward, Philip has made several attempts to deal with voicelessness. She considers that the English language is contaminated and therefore needs to be purified: "the word only comes alive in the silence." (Philip 2010) Silence is often sacred in Zong! because the poet aims to "defend the dead" (200). The blank on the page may thus reflect the lack of defence and the slaves' absent voices in history. By recreating the sacred voices of the slaves and allowing silence to be voiced in the poetic space, not only does Philip free the spirit of her ancestors, but she also endorses the role of the lawyer, her past profession, picturing the Law as drowned in her poetry. An absurd law, an insurance contract, the thirst for money, financial necessity... all the justifications that could have accounted for the tragedy are silenced:

There is no evidence in the against of winds

the consequence of currents or the apprehension of rains

the certain of value or the value of certain

against the rest in preservation

the save in residue (34)

The antimetabole playing on the words "value" and "certain" in reverse order foregrounds the ambiguity of the notion of value. The names of the slaves which are always present below the bottom line constantly remind the reader of their enduring spiritual presence. Moreover, the voices of the slaves are often perceived as being linked to the sacred. They are heard praying and invoking the names 
of Yoruba deities such as Ogun, the god of iron, and African divine names such as "Esu" "Ifa" or "Efun." All of them are recurrently mentioned in the book, underlining the continuing prayers of the dying slaves but also the sacred aspect of language for Philip. To some degree, Barbadian poet Edward Kamau Brathwaite also regards as sacred what he calls "Nation Language." Brathwaite actually argues that Nation Language stems from African oral tradition, and that, in poetry, it produces musical rhythms which differ from English canonical iambic rhythms (Brathwaite 1984, 13-14). In a fashion analogous to Brathwaite's, Philip's Zong! appears to distinguish itself from traditional English speech rhythms as it enhances African Caribbean rhythms which are closer to calypso and reggae. For NourbeSe Philip, Zong! is like a sacred song. While writing the book-length poem, her fingers would often hit the "S" key instead of the expected "Z," transforming the name "Zong" into the word "Song." As for the question pertaining to the function of the exclamation mark after Zong! she replies in her afterword to the book:

Zong! is chant! shout! And ululation! Zong is moan! Mutter! Howl! And shriek! Zong! is pure utterance. Zong! is Song! And Song is what has kept the soul of the African intact when they wanted water... sustenance... preservation. Zong! is the Song of the untold story; it cannot be told yet must be told, but only through its un-telling. (207)

In fact, Zong! is a multi-vocal song, one in which history, culture and religion are seen from multiple perspectives, as both Christian references and African religious symbols are enhanced. While NourbeSe Philip gives an important place to African spirituality in her work, perhaps to challenge what she perceives as demonization of African-based religions in modern societies, she also acknowledges the crucial part of the Judaeo-Christian tradition in the survival of African peoples in the New World. In fact, Zong! weaves together both biblical references and African religious symbols. The final scene in the book has a strong biblical resonance, as a sailor transcribes a letter from Wale the slave to his wife Sade. Wale then eats the letter before falling overboard, and he is followed by the sailor who wrote the letter for him. This swallowing of the "word" is reminiscent of the beginning of the Book of Ezekiel in the Old Testament, in which the prophet is forced to swallow the divine word which "was written within and without and there was written therein lamentations and mourning and woe." (Ezek. 2:10b) Like the sailor in the final scene, Ezekiel is forced to dictate and enact "the chronicle of a death foretold and anticipated." (Hartman 3) The correlation between the Book of Ezekiel and Zong! also has diasporic resonances, as the Prophet Ezekiel was forced to announce the unavoidable destruction of Jerusalem and the consequent exile of the Jewish people, now considered the most ancient Diaspora.

The poet therefore acts as a detective who goes beyond the silent archive, interpreting it against presupposed "historical truth," transcending linguistic boundaries and bondage. As she explains in the afterword to the collection: 
Within the boundaries established by the words and their meanings there are silences; within each silence is the poem, which is revealed only when the text is fragmented and mutilated, mirroring the fragmentation and mutilation that slavery perpetrated on Africans, their customs and ways of life. (195)

The recurrence of the African divination system "Ifa" and the mention of the "Oba," the African ruler who sobs at the end, convey the impossibility for the Oba to express fully what happened aboard the Zong. Consequently, the narrative Wale swallowed expresses the unalterable reality of a part of mankind being thrown overboard. It may also reflect the poet's invitation to ingest the narrative. NourbeSe Philip demonstrates that even where the archive is silent, words are still pregnant with meaning:

The loss of stories sharpens the hunger for them. So it is tempting to fill in the gaps and to provide closure where there is none. To create a space for mourning where it is prohibited. To fabricate a witness to a death not much noticed. (Hatman 3)

Silence can also be exploited by the reader who becomes a co-producer of the text, interpreting silences and gaps, elucidating Philip's puns in different languages and the "secret order / among syllables." (Philip 1993, 37). The reader has to participate in meaning-making while reading the text, dealing with the lacunae that sustain silence. Besides, the poetess is in a position to control the vision of her readers, as she forces them to enlarge their perspective, so as to be able to remap new spaces and reconstruct a fragmented past, a forgotten or unknown history: "the not-telling of this particular story is in the fragmentation and mutilation of the text, forcing the eye to track across the page in an attempt to wrest meaning from words gone astray." (198)

M. NourbeSe Philip's work appears to be a trans-spatial and trans-temporal text, insofar as her poetry strives to transcend the boundaries of space and time. Her writing intimates how unlimited and unbound diasporic spaces are, as the Diaspora constantly displaces home and away, here and elsewhere, defining the limits of its own horizon, whether it be imagined, metaphysical or material. The problematic fragmentation and gaps in language have shaped Philip's poetry, and she has often tackled the issue of writing in a foreign language, languish, anguish, "this language of grunt and groan, of moan and stutter - this language of pure sound fragmented and broken by history." (205) In Zong!, Philip addresses the gaps in the medium for expression, the underlying fragmentation beneath Caribbean polyvocality. In 1974, Barbadian poet Edward Kamau Brathwaite's declaration that "the unity is submarine" summarized the complex overlapping realities and the cross-cultural roots of the Caribbean (Brathwaite 1974, 64). The sea between the Caribbean diasporic female subject and her past, the same sea that NourbeSe Philip crossed in order to visit Ghana, is symbolised through the crossing of spatial and temporal gaps. Philip's journey to West Africa as well as her various forms of research in trying to locate the fragments of her traumatic past are important, because they embody the several dimensions of her diasporic 
experience. The poet participates in the tradition of neo-slave narratives which is more recent for African Caribbean women writers than for their African American counterparts. By relating the Zong tragedy, Philip re-creates the horizons the African slaves could never reach, re-imagines and re-interprets their drowning, and "the past is laid to rest when it is told" (D'Aguiar 1997, 230). This past drowning is now linked to a possible resurrection, and re-writing slavery allows the poet to come to terms with her traumatic history. As Fred D'Aguiar argues in "The Last Essay about Slavery," it is essential to try to imagine "a last poem, a last play, a last novel, a last song about slavery that would 'kill slavery off' as some 'final acts of creativity' that would somehow disqualify any future need to return to it." (D'Aguiar 1996, 125). It is then necessary to return to the past in order to move on. In some recent diasporic Caribbean women's neo-slave narratives, moving on has been allegorised through the resurrection which actually occurs in the story. In her novel Humus, Martinican author Fabienne Kanor author(ize)s one of her African female enslaved protagonists to survive after she threw herself overboard. Through her survival and consequent freedom, the re-born African woman has the possibility to re-claim her African ancestry, to assert her identity as well as to express her own desires. Phlilip's experimental writing in Zong! also allows her to resurrect her African history, re-connect with it, and create new horizons accordingly. In this sense, "The African, transformed into a thing by the law, is re-transformed, miraculously, back into human." (199) The transcending voices that resonate in the collection Zong!, their limitless and multi-horizoned space and time are foreshadowed in Mutabaruka's dub poem:

Dis poem shall speak of the wretched sea that washed ships to these shores Of mothers cryin for their Young swallowed up by the sea dis poem shall say nothin new dis poem shall speak of time time unlimited time undefined [...] dis poem is to be continued in your mind. (462)

Myriam MOÏSE Université de Paris 3 - Sorbonne Nouvelle Université des Antilles et de la Guyane 


\section{Works Cited}

Baucom, Ian. "Specters of the Atlantic." The South Atlantic Quarterly 100.1 (2002): 61-82.

Brathwaite, Edward Kamau. History of the Voice: The Development of Nation Language in Anglophone Caribbean Poetry. London: New Beacon. 1984.

-. Contradictory Omens: Cultural Diversity and Integration in the Caribbean. Mona: Savacou Publications. 1974.

Castellanos, Rosario. "Language as an Instrument of Domination." Women Writing Resistance: Essays on Latin America and the Caribbean. Ed. J. Browdy De Hernandez. Cambridge: South End P, 2003. 73-78.

CÉSAIRE, Aimé. Ferrements. Paris: Seuil, 1960.

D'Aguiar, Fred. Feeding the Ghosts. London: Chatto and Windus. 1997.

- . "The Last Essay about Slavery." The Age of Anxiety. Ed. Sarah Durant and Roy Porter. London: Virago. 1996. 125-147.

Derrida, Jacques. "Des tours de Babel." Difference in Translation. Ed. Joseph Graham. Ithaca: Cornell UP, 1985. 209-248.

Dupriez, Bernard. A Dictionary of Literary Devices: Gradus, A-Z. Trans. A.W. Halsall. Toronto: U of Toronto P, 1991.

Goodison, Lorna. "Mother, the Great Stones Got to Move." To Us All Flowers Are Roses. Champaign: U of Illinois P. 1995. 4-5.

Hartman, Saidiya. "Venus in Two Acts." Small Axe 26 (June 2008): 1-14.

Kanor, Fabienne. Humus. Paris: Gallimard, 2006.

KogawA, Joy. Obasan. New York: Anchor Books, 1994.

Morrison, Toni. The Bluest Eye. New York: Plume,1970.

Murphy J. M., and Sanford M. M. Osun Across the Waters: A Yoruba Goddess in Africa and the Americas. Bloomington: Indiana UP, 2001.

Mutabaruka. "Dis Poem." The Routledge Reader in Caribbean Literature. Ed. A. Donnell and S. L. Welsh. London: Routledge, 1996. 462-463.

Philip, M. NourbeSe. A Genealogy of Resistance and Other Essays. Toronto: Mercury P, 1997.

—. Personal Interview. Port of Spain, February 2010

—. She Tries Her Tongue, Her Silence Softly Breaks. Charlottetown: Ragweed P, 1989.

—. Zong! Middletown: Wesleyan UP, 2008.

Shange, Ntozake. Liliane: Resurrection of the Daughter. New York: St. Martin's P,1994.

WalcotT, Derek. "The Sea is History." The Star-Apple Kingdom. New York: Farrar, Strauss and Giroux, 1979. 